\title{
Hydrolyzed Organic Fish Fertilizer and Poultry Litter Influence Yield and Rhizosphere Ecology of Sweetpotato
}

\author{
Lauren Lindsey ${ }^{1}$, Raymon Shange, Ramble O. Ankumah, \\ Desmond G. Mortley ${ }^{2}$, and Sangita Karki \\ College of Agriculture, Environment and Nutrition Sciences and G. W. \\ Carver Agricultural Experiment Station, Tuskegee University, Tuskegee \\ AL 36088
}

Additional index words. amendments, carbon, nitrogen, enzyme activity, bacterial ecology

\begin{abstract}
Organic fertilization techniques have become an attractive alternative to conventional techniques, but there remains interest in their impact on rhizosphere ecology. This study was aimed at assessing the impacts of various organic fertilizer amendments on storage root yield, chemical, biochemical, and microbial factors in the rhizosphere ecosystem and the bacterial community composition in the rhizosphere ecosystem. Four sweetpotato cultivars (J6/66, NCC-58, TU Purple, and Whatley/Loretan) and four organic fertilizer treatments [poultry litter, Megabloom (fish protein), NPK, and an untreated control] were used in the study. The experiments were conducted as a randomized complete block design with a $4 \times \mathbf{4}$ factorial treatment arrangement and three replications. Fertilizer treatments were split-applied at the rate of 134-67-67 kg.ha ${ }^{-1}$ NPK equivalent based on soil test recommendations 1 and 4 weeks after planting as single bands $15 \mathrm{~cm}$ from the plants and organic amendments were calculated based on total $N$ content. Rhizosphere soil samples were collected at harvest and analyzed for soil $\mathrm{pH}$, soil organic carbon (SOC), bacterial 16S rDNA, and selected soil enzymes. Organic amendments did not affect storage root yield or percent dry matter but enhanced both the mass and number of US\#1 storage roots. Rhizosphere $\mathbf{p H}$ varied depending on cultivar and cultivar response varied with $\mathbf{p H}$ and ranged from 6.1 to 6.8, whereas SOC was similar regardless of the amendment. The impact of fertilizers was evident as Megabloom (fish protein) treatment suppressed the relative abundance (RA) of nitrifiers (Nitrosococcus and Nitrosomonadaceae). Also, the rhizosphere of 'Whatley/Loretan' seemed to have been a beneficial habitat for populations of common nitrogen-fixing bacteria Bradyrhizobium elkanii, and Rhodospirillaceae sp. as their RA increased significantly in the rhizosphere. That bacteria associated with carbon and nitrogen cycling under aerobic conditions were found to be ubiquitous in the rhizosphere of sweetpotato, suggesting that certain amendments positively impacted the populations of nitrogen-cycling bacteria, thus making them a viable alternative to NPK when considering increasing or sustaining yield while promoting long-term soil health.
\end{abstract}

Sweetpotato [Ipomea batatas (L.) Lam.] is a tropical root crop that belongs to the Convolvulaceae or morning glory family. It is a creeping dicotyledonous plant and an important crop, widely grown in tropical, subtropical, and warm temperate regions. It ranks the world's seventh most important crop, with an estimated annual production

Received for publication 8 Nov. 2018. Accepted for publication 6 Feb. 2019

Contribution of the George Washington Carver Agricultural Experiment Station, Tuskegee University. This research was supported by funds from U.S. Department of Agriculture/National Institute of Food and Agriculture Evans-Allen Grant No. ALX-FV. The authors extend deep gratitude toward all the staff at Tuskegee University George Washington Carver Agricultural Experiment Station

${ }^{1}$ Former graduate student. Current address: Department of Crop, Soil, and Environmental Sciences, College of Agriculture, Auburn University, Auburn, AL 36849.

2Corresponding author. E-mail: dmortley@tuskegee. edu.
$21 \mathrm{~d}$ after transplanting produced greater yields of US\#1 storage roots compared with a higher rate. Villordan et al. (2013) reported that lateral root length of storage roots increased substantially as $\mathrm{N}$ rates increased from 0 to $50 \mathrm{~kg} \cdot \mathrm{ha}^{-1}$, whereas increasing the $\mathrm{N}$ rates to either 100 or 200 $\mathrm{kg} \cdot \mathrm{ha}^{-1}$ did not result in any further increases in root growth.

Organic amendments were the primary soil amendments until the innovations and techniques of the Green Revolution (Horne, 2008). Inorganic fertilizers began to replace organic fertilizers as producers have relied on them to maintain production demands to keep pace with population growth. In addition, most $\mathrm{N}$ based fertilizers are produced from fossil fuels, which have increased in price exponentially over the past decade (Wen-yuan, 2007). With increasing concerns over fertilizer pricing and reports of negative effects attributed to its use, organic fertilizers and organic practices have received renewed interest.

Organic production in the United States has grown since the inception of national organic production and labeling standards in 2002 (Baker, 2005). Several studies have shown that organic production is comparable to conventional systems in terms of yield; however, organic systems had enhanced microbial biomass and activity, increased soil organic matter, increased nutrient pools, and other soil properties (Delate et al., 2003; Klonsky, 2000). A study comparing compost with or without cover crops and tillage on organic vs. conventional sweetpotato production showed that leaf $\mathrm{N}, \mathrm{P}$, and $\mathrm{K}$ concentrations were greatest in the compost/ cover crop combination compared with the other systems (Treadwell et al., 2008). Other studies found greater $\mathrm{P}, \mathrm{Mg}$, and Fe levels in organic systems and those mineral nutrients were on average higher in organically grown crops though results were somewhat inconclusive (Worthington, 2001).

The soil-microbial-plant system holds the capacity to sustain nutrient demands ecologically and efficiently due to the high amounts of nutrients that pass through the microbial biomass (Kennedy, 1995). Soil microorganisms drive most soil processes, such as nutrient cycling, availability, and retention; decomposition of organic materials; and soil organic matter accumulation primarily through the utilization of enzymes (Coleman et al., 2004). Alterations in the physical and chemical nature of soils may lead to shifts in the composition of the microbial community and changes in microbial function. Rhizosphere contains beneficial microorganisms that displace harmful microorganisms through aggressive colonization or through the production of plant growth hormones such as auxins and kiritin (Herman et al., 2008). The rhizosphere has a large impact on plant performance in several ways, as it not only supports the plant in the acquisition of water and nutrients, but also helps modulates the plant's ability to cope with pathogens as well as supports high diversity of microorganisms. Studies have 
shown that different growth stages of plants can influence the rhizosphere microbes, due to changes in rhizodeposition. For example, young roots can supply more energy to soil microorganisms, as they produce more exudates than older roots (Bowen and Rovira, 1976; Hawes et al., 2012; Lynch and Whipps, 1990). Plant growth-promoting rhizobacteria are free-living, soil-borne bacteria that colonize the rhizosphere and, when applied to crops, enhance the growth of plants. Plant growth-promoting rhizobacteria may enhance plant growth either by direct or indirect mechanisms including nitrogen fixation (Vessey, 2003). In the past, understanding the complex diversity of soil microorganisms was limited because only a small portion of soil microbial populations can be cultured and identified using standard approaches. For instance, several studies have used soil enzymes to assess changes in soil, as soil enzymes are an essential part of microbial communities in soil systems and are strongly influenced by changes in microbial community composition (Ndiaye et al., 2000; Sun et al., 2004). The $\beta$-glucosidase ( $\beta$-GLU) and $\mathrm{N}$-acetyl- $\beta$ glucosaminidase ( $\beta$-NAG), and phosphatase enzymes [acid phosphatase (ACP) and alkaline phosphatase (ALKP)] were used for this study because they are known to be sensitive to soil management and have been proposed as soil quality indicators because their ability to provide early indications of changes in organic matter status (Ekenler and Tabatabai, 2003; Moore-Kucera and Dick, 2008). However, use of high-throughput sequencing techniques, such as 454 pyrosequencing of $16 \mathrm{~S}$ ribosomal RNA (rRNA) gene has allowed for the exploration of microbial communities' structure and taxonomic composition at greater depth and increased the current knowledge of soil microbial communities (Bruinsma et al., 2003; Lauber et al., 2009; Shange et al., 2012). Pyrosequencing has also been shown to detect changes in microbial communities due to organic and conventional farming and increasing current knowledge about the influence of organic amendments has on soil microbial communities (Chaudhry et al., 2012; Leff and Fierer, 2013; Li et al., 2012; Sugiyama et al., 2010; Widmer et al., 2006).

The objectives of the study were to assess the impacts of various organic fertilizer amendments on storage root yield, and chemical and biochemical factors of the rhizosphere ecosystem, and the bacterial community composition in the rhizosphere ecosystem.

\section{Materials and Methods}

The study was conducted as a randomized complete block design with a $4 \times 4$ factorial treatment arrangement and three replications. The treatment combinations were conventional NPK fertilizer, poultry litter, Megabloom (hydrolyzed fish protein fertilizer), and an untreated check. The sweetpotato cultivars were J6/66, NCC-58, TU Purple, and Whatley-Loretan. The soil type at the study site was Norfolk sandy loam (fine, siliceous, thermic Typic, Paleudults) with a
$\mathrm{pH}$ of $\approx 5.9$ and organic matter content of $<1 \%$. The field was prepared conventionally and soil samples were collected for elemental analysis at $15-\mathrm{cm}$ depths. The cores were composited and analyzed by the Plant and Soil Testing Laboratory at Auburn University for mineral constituents $(\mathrm{Ca}, \mathrm{Mg}, \mathrm{P}, \mathrm{K}, \mathrm{pH})$.

Treatment calculations and planting. Treatments were split-applied at the rate of 134-67-67 kg.ha ${ }^{-1}$ NPK equivalent based on soil test recommendations 1 and 4 weeks after planting as single bands $15 \mathrm{~cm}$ from the plants and organic amendments were calculated based on total $\mathrm{N}$ content. Poultry litter, unlike commercial fertilizers, is quite variable, and according to Fulhage and Pfost (1994) can vary up to $50 \%$ based on animal sources. Available values of litter nutrients using data from Fulhage and Pfost (1994) were total $\mathrm{N}$ of $27 \mathrm{~kg} \cdot$ ton $^{-1}$, composed of 24 $\mathrm{kg} \cdot$ ton $^{-1}$ organic $\mathrm{N}$ and $3 \mathrm{~kg} \cdot \mathrm{ton}^{-1} \mathrm{NH}_{4} \mathrm{~N}, 29.5$ $\mathrm{kg} \cdot \operatorname{ton}^{-1} \quad \mathrm{P}_{2} \mathrm{O}_{5}$, and $19 \mathrm{~kg} \cdot \operatorname{ton}^{-1} \mathrm{~K}_{2} \mathrm{O}$. In addition, the amount of organic $\mathrm{N}$ available was based on days from collection to incorporation, which is $20 \%$ beyond 7 days. Calculations were based on the following equation:

$$
\frac{\operatorname{crop} \mathrm{N}-\text { residual } \mathrm{N}}{\text { available } \mathrm{NH}_{4-} \mathrm{N}+\text { available organic } \mathrm{N}}
$$

Ten stem cuttings of each sweetpotato cultivar were transplanted into 3-row plots $1.2 \mathrm{~m} \times 3 \mathrm{~m}$ with an in-row spacing of $0.3 \mathrm{~m}$ and plants drip irrigated as needed.

Harvest and rhizosphere soil analysis. Plants were harvested from the middle row of each plot by cutting the vines at ground level and fresh weights of foliage and storage roots were recorded. Subsamples of foliage and storage roots (US\#1 grade) were dried for $72 \mathrm{~h}$ at $70{ }^{\circ} \mathrm{C}$. This dry weight information was used to calculate a fresh-to-dry weight conversion factor to determine storage root dry weight. Percent dry matter (DM) [(dry weight/fresh weight $) \times 100$ ] was calculated for storage roots.

Triplicate rhizosphere soil samples from each plot were taken at harvest, dried and analyzed for $\mathrm{pH}$, soil organic carbon (SOC), and enzyme activity. Soil $\mathrm{pH}$ was determined using 1:2.5 soil/water and SOC using the wet oxidation method (Walkley and Black, 1934). Phosphomonoesterase activity was measured by the method of Tabatabai and Dick (2002); $\beta$-GLU and $\beta$-NAG activity by referenced assays (Eivazi and Tabatabai, 1977; Parham and Deng, 2000).

Whole DNA was extracted from $\approx 0.25 \mathrm{~g}$ of soil (oven dry basis of field-moist soil) using the Power Soil Extraction Kit (MO BIO Laboratories, Soloana Beach, CA). Extracted DNA $(2 \mu \mathrm{L})$ was quantified using Nanodrop ND-1000 spectrophotometer (Nanodrop Technologies, Wilmington, DE). Following extraction and quantification, the samples were then submitted to MRDNA Laboratories (Shallowater, TX) for polymerase chain reaction (PCR) optimization and sequence analysis. The $16 \mathrm{~S}$ rRNA gene V4 variable region PCR primers 515/806 were used in a single-step 30 cycle PCR using the HotStarTaq Plus Master Mix Kit (Qiagen, Valencia, CA). Sequencing was on an Ion Torrent PGM (Roche, Brandford, CT) following the manufacturer's guidelines. The resulting sequence data were processed using an analysis pipeline developed at MR DNA Laboratories [e.g., the removal of barcodes and primers, sequences $<150$ base pairs (bp) removed, sequences with ambiguous base calls and with homopolymer greater than 6 bp]. Sequences were denoised, operational taxonomic units (OTUs) generated and chimeras removed. OTUs were defined by clustering at 3\% divergence ( $97 \%$ similarity). Final OTUs were taxonomically classified using BLASTn against a database derived from RDPII (http://rdp.cme.msu.edu) and National Center for Biotechnology Information (NCBI; www.ncbi.nlm.nih.gov). Samples are being submitted to the NCBI Sequence Read Archive. OTUs were then compiled into every taxonomic level into count files that actual number of sequences for each taxonomic classification, and the percentage files that contained the proportion percentage of sequences at each taxonomic classification for each sample.

All data were subjected to analysis of variance (ANOVA) using the general linear model procedure (SAS Institute, 2009). Treatment and cultivar means were separated by Tukey-Kramer's test at the 0.05 level of probability.

\section{Results and Discussion}

Biomass production. The main effect of organic amendments on storage root yield and percent DM (Table 1) show that organic amendments had no significant impact on total storage root yield or DM, but did influence the yield of US\#1 storage roots. The yield of US\#1 storage roots was highest for plants in which poultry litter (PL) was applied relative to that of control plants but not different from plants receiving Megabloom (fish hydrolysate) or NPK. However, plants receiving $\mathrm{PL}$ or Megabloom produced a greater number of US\#1 storage roots compared with NPK or the control plants. Similarly, cultivar had no significant influence on total storage root yield or on the number of US\#1storage roots produced (Table 2), although 'Whatley/Loretan' produced the highest yield of $26 \mathrm{t} \cdot \mathrm{ha}^{-1}$. Organic amendments had no significant impact on DM (Table 1) and the major influence was based on variety (Table 2 ), with 'TU Purple' having the highest DM. These DM levels are consistent with these respective varieties when grown in the field.

A contrast of fertilized vs. nonfertilized plants show that on a whole, plants that received nutrient amendments produced greater yields and numbers of US\#1 storage roots only while a contrast of organic vs. inorganic showed that organic amendments enhanced yield of US\#1 storage roots. These results show that organic amendments exerted greater impact on yield of US\#1 storage roots 
Table 1. The main effect of organic amendment on total storage and US\#1 root yield, number of US\#1 and percent dry matter (DM) of four sweetpotato cultivars.

\begin{tabular}{|c|c|c|c|c|}
\hline & \multicolumn{4}{|c|}{ Storage root yield } \\
\hline & Total & US\#1 & \multirow[b]{2}{*}{ US\#1 (no./plot) } & \multirow[b]{2}{*}{$\mathrm{DM}(\%)$} \\
\hline & \multicolumn{2}{|c|}{$\left(\mathrm{t} \cdot \mathrm{ha}^{-1}\right)$} & & \\
\hline \multicolumn{5}{|l|}{ Treatment } \\
\hline Control & $12.0 \mathrm{a}$ & $7.9 \mathrm{~b}$ & $7.7 \mathrm{c}$ & $28.3 \mathrm{a}$ \\
\hline Poultry litter & $19.7 \mathrm{a}$ & $14.2 \mathrm{a}$ & $13.3 \mathrm{a}$ & $26.4 \mathrm{a}$ \\
\hline Megabloom & $18.1 \mathrm{a}$ & $9.9 \mathrm{ab}$ & $12.9 \mathrm{a}$ & $27.5 \mathrm{a}$ \\
\hline NPK & $21.2 \mathrm{a}$ & $10.6 \mathrm{a}$ & $10.6 \mathrm{~b}$ & $27.9 \mathrm{a}$ \\
\hline Significance $^{z}$ & $\mathrm{NS}^{\mathrm{x}}$ & 0.001 & 0.001 & NS \\
\hline \multicolumn{5}{|l|}{ Contrast } \\
\hline Fertilizer vs. nonfertilized & NS & 0.002 & 0.001 & 0.10 \\
\hline Organic vs. inorganic & NS & 0.01 & 0.07 & NS \\
\hline BL vs. Fish & NS & NS & NS & NS \\
\hline
\end{tabular}

${ }^{\mathrm{z}}$ Means within columns accompanied by the same letter are not significantly different according to TukeyKramer's test at 0.05 level of probability.

NS $=$ nonsignificant.

Table 2. The main effects of organic amendment on total storage and US\#1 root yield, number of US\#1 and percent dry matter (DM) of four sweetpotato cultivars.

\begin{tabular}{|c|c|c|c|c|}
\hline & \multicolumn{4}{|c|}{ Storage root yield } \\
\hline & Total & US\#1 & \multirow[b]{2}{*}{ US\#1 (no./plot) } & \multirow[b]{2}{*}{ DM $(\%)$} \\
\hline & \multicolumn{2}{|c|}{$\left(\mathrm{t} \cdot \mathrm{ha}^{-1}\right)$} & & \\
\hline \multicolumn{5}{|l|}{ Cultivar } \\
\hline TU Purple ${ }^{\mathrm{z}}$ & $17.3 \mathrm{a}$ & $14.2 \mathrm{a}$ & $11.0 \mathrm{a}$ & $32.3 \mathrm{a}$ \\
\hline$J 6 / 66$ & $12.5 \mathrm{a}$ & $9.0 \mathrm{~b}$ & $10.2 \mathrm{a}$ & $30.4 \mathrm{~b}$ \\
\hline NCC-58 & $14.9 \mathrm{a}$ & $11.6 \mathrm{ab}$ & $11.3 \mathrm{a}$ & $23.8 \mathrm{c}$ \\
\hline Whatley/Loretan & $26.3 \mathrm{a}$ & $10.4 \mathrm{ab}$ & $11.1 \mathrm{a}$ & $22.7 \mathrm{c}$ \\
\hline Significance $^{\mathrm{z}}$ & NS & 0.03 & NS & 0.0001 \\
\hline \multicolumn{5}{|l|}{ Contrast } \\
\hline Fertilizer vs. nonfertilized & NS & 0.002 & 0.001 & 0.10 \\
\hline Organic vs. inorganic & NS & 0.01 & 0.07 & NS \\
\hline Poultry Litter vs. Megabloom & NS & NS & NS & NS \\
\hline
\end{tabular}

${ }^{\mathrm{z}}$ Means within columns accompanied by the same letter are not significantly different according to TukeyKramer's test at 0.05 level of probability.

NS $=$ nonsignificant.

and number but did not influence total yield or storage root DM.

Nutrients in organic fertilizer are released through mineralization by the activity of soil microorganisms. Depending on existing soil conditions including $\mathrm{pH}$ and moisture status, mineralization rates can be impacted, and it is probable that the lack of total yield response to organic amendments in this study could be related in part to slower mineralization rates resulting in fewer nutrients available for plant uptake (Boyhan et al., 2010). As mineralization rates of PL have been reported as slow (Whitmore, 2007), researchers in the region have suggested applying organic fertilizer 14 to $20 \mathrm{~d}$ earlier than normal to compensate for slow mineralization rates. These results suggest that plant responses would be more positive in subsequent years.

Soil $\mathrm{pH}$ and organic carbon. There were significant interactions between fertilizer amendments and cultivar for rhizosphere $\mathrm{pH}$ (Table 3). Rhizosphere $\mathrm{pH}$ varied depending on cultivar and cultivar response varied with $\mathrm{pH}$ and ranged from 6.1 to 6.8 . The results suggest that the organic amendments lowered rhizosphere $\mathrm{pH}$ values in 'Whatley/ Loretan' and 'NCC-58' treated with Megabloom and 'TU Purple' plots receiving PL having the lowest $\mathrm{pH}$ values. Cultivar influenced SOC (Table 3) in the rhizosphere and the highest activity. Even though plots treated with Megabloom had marginally lower activity relative to the other treated plots, it was still $40 \%$ greater than in control plots. Similarly, as with ALKP, all three amendments increased the activity of $\beta$-GLU 3 -fold, with NPK-treated plots having the highest activity followed by Megabloom and PLtreated plots. Thus the control plots had lower enzyme activity, whereas those receiving fertilizer amendments had greater activity, suggesting that the organic amendments did not adversely affect enzyme activity relative to NPK-treated plots (Table 4).

The addition of organic amendments increased soil enzyme and microbial activity, which is consistent with what others have reported (Edmeades, 2003; Gutierrez-Miceli et al., 2007) . Further, activities of most soil enzymes increase as soil substrate increases, reflecting larger microbial communities, and increased stabilization of enzymes by humic materials (Burns, 1983). Provocation of enzymatic activity can also be a result of the release of exudates in the rhizosphere ecosystem. These exudates can thus activate the microbial synthesis of intracellular and extracellular enzymes. In contrast, the C-rich exudates can also serve as an energy source for microbial production of extracellular enzymes that increase decomposition activities (Gianfreda, 2015). In addition to exudate release and pathogen control, one of the most important functions in the bacterial community of the rhizosphere is phosphate solubilization. As this process is stewarded by bacteria and the extracellular enzymes that they produce (ACP, ALK, and more), the results showing increased activity of phosphatase enzymes substantiate the literature that soil amendments (inorganic and organic) have a stimulating impact on rhizosphere phosphatase (Ai et al., 2012).

Bacterial community composition. In terms of the bacterial ecology, the results for the phyla and class level (Fig. 1) indicated that Proteobacteria was the most dominant phylum and class identified. When considering the class level of taxonomy (of which certain groups become more functionally evident) (Shange et al., 2012), four classes of Proteobacteria (Alphaproteobacteria, Betaproteobacteria, Deltaproteobacteria, Gammaproteobacteria), as well as the class Actinobacteria were the most prevalent in the class groups. 'TU Purple' and 'Whatley/Loretan' significantly influenced Gemmatimonadetes at every taxonomic level, suggesting that these cultivars produce root exudates that may have attracted these bacteria.

Taxonomic response to fertilizer treatment. There were 27 genera present in the rhizosphere samples. Significant effects were observed for amendments on the populations of Flexibacter, Mycobacterium, Nitrosococcus, Nitrosomonadaceae, and Roseiflexus (Table 5). Of the 1896 species observed, 30 were in great quantities in the rhizosphere samples. The ANOVA showed that organic amendments had the greatest effect on species composition. Megabloom significantly decreased the bacterial relative abundance (RA) of Nitrosococcus, 
Nitrosomonadaceae, and Flexibacter genera compared with the control and the other amendments except PL, where the RA was not different for Nitrosococcus and Nitrosomonadaceae (Table 5). In contrast, Megabloom increased the populations of Mycobacterium and Rubrobacter compared with the control (Table 5). NPK increased Nitrosomonadaceae, whereas Megabloom increased the RA of Gemmatimonas, Mycobacterium, and Rubrobacter genera, and decreased the RA of Flexibacter, Nitrosococcus, Nitrosomonadaceae, and Roseiflexus genera. Thus, Megabloom continued to impact bacterial populations at the species level as it had at the genus level compared with the control. For example, Novosphingobium sp. decreased significantly compared with the control and other amendments, whereas the $\mathrm{RA}$ of Rhodospirillaceae sp. increased in plots receiving NPK and organic amendments compared with the control plots (Table 5). The addition of fertilizer and organic amendments had a significant impact on bacteria at every taxonomic level compared with the control; however, Megabloom and PL organic rhizosphere soils had similar or significantly different effects on $\mathrm{RA}$ at the genus and species taxonomy level compared with rhizosphere soils amended with inorganic fertilizers.

These results demonstrate that at the genus and species levels of taxonomy, the type of fertilizer, and the type of organic substrate influence the changes in some of the most abundant groups in the rhizosphere ecosystem. Not only are there changes to the composition of the community that seem to be functionally obtuse, there were changes to taxa that have been identified as playing important functional roles in the soil ecosystem. Nitrosomonadaceae is a family that includes Nitrosomonas, Nitrosospira, and Nitrosovibrio lithotrophic ammonia oxidizing bacteria (AOB). Nitrosococcus, another AOB from the Gammaproteobacteria class responded positively to the treatments. Although Flexibacter is well known for its fish pathogenicity (Crump et al., 2003), there have been other isolates found in soils that participate in denitrification $(\mathrm{Wu}$ et al., 1994). As this process requires net $\mathrm{NO}_{3}-\mathrm{N}$ availability, there may have been a lower availability of $\mathrm{NO}_{3}-\mathrm{N}$ due to the slow release of N from Megabloom (Mikkelsen and Hartz, 2008). It would be reasonable to surmise that soil Flexibacter would reduce RA in such an environment. Although PL is also a slowrelease organic fertilizer, it has been stated that rates of mineralization can be highly variable (Gaskell and Smith, 2007). Further evidence to substantiate this notion is the parallel RA of the nitrifiers (Nitrosococcus and Nitrosomonadaceae). The statistical significance of RA of the nitrifying bacteria relative to the control might be due to soil environment factors. According to Wang et al. (2015), soil $\mathrm{pH}$ value, number of ions, $\mathrm{NH}_{4}^{+}$, soil temperature, and organic matter content have a critical impact on the bacterial population.

Table 3. Statistical significance from analysis of variance of fertilizer amendments, cultivar and fertilizer amendments $\times$ cultivar interaction for soil $\mathrm{pH}$, organic carbon, and enzyme activities.

\begin{tabular}{lccccccc}
\hline Source of variation & $\mathrm{df}$ & $\mathrm{pH}$ & $\% \mathrm{C}$ & $\mathrm{ACP}$ & ALKP & $\beta-\mathrm{NAG}$ & $\beta-\mathrm{GLU}$ \\
\hline Amendments & 3 & $\mathrm{NS}$ & $\mathrm{NS}$ & 0.02 & 0.005 & 0.01 & 0.03 \\
Cultivar & 3 & $\mathrm{NS}$ & 0.02 & $\mathrm{NS}$ & $\mathrm{NS}$ & $\mathrm{NS}$ & $\mathrm{NS}$ \\
Amendments $\times$ Cultivar & 9 & 0.001 & $\mathrm{NS}$ & $\mathrm{NS}$ & $\mathrm{NS}$ & $\mathrm{NS}$ & $\mathrm{NS}$ \\
\hline
\end{tabular}

$\overline{\mathrm{ACP}}=$ acid phosphatase; $\mathrm{ALKP}=$ alkaline phosphatase; $\beta-\mathrm{GLU}=\beta$-glucosidase; $\beta-\mathrm{NAG}=$ $\beta$-glucosaminidase; $\mathrm{NS}=$ nonsignificant.

Table 4. Main effect of fertilizer amendments on soil enzyme activity.

\begin{tabular}{lclcc}
\hline & ACP & ALKP & $\beta-N A G$ & $\beta-G L U$ \\
\cline { 2 - 5 } Fertilizer amendments & \multicolumn{4}{c}{$\mu$ g p-nitrophenol/g soil/hr } \\
\hline Control & 172.9 & 2.2 & 16.6 & 13.1 \\
Poultry litter & 287.7 & 7.1 & 31.4 & 45.9 \\
Megabloom & 329.9 & 7.4 & 23.1 & 48.3 \\
NPK & 308.7 & 7.7 & 29.4 & 49.5 \\
Significance & 0.05 & 0.01 & 0.002 & 0.01 \\
\hline
\end{tabular}

$\overline{\mathrm{ACP}}=$ acid phosphatase ALKP $=$ alkaline phosphatase $; \beta-\mathrm{GLU}=\beta$-glucosidase $; \beta-\mathrm{NAG}=$ $\beta$-glucosaminidase.

Phylum

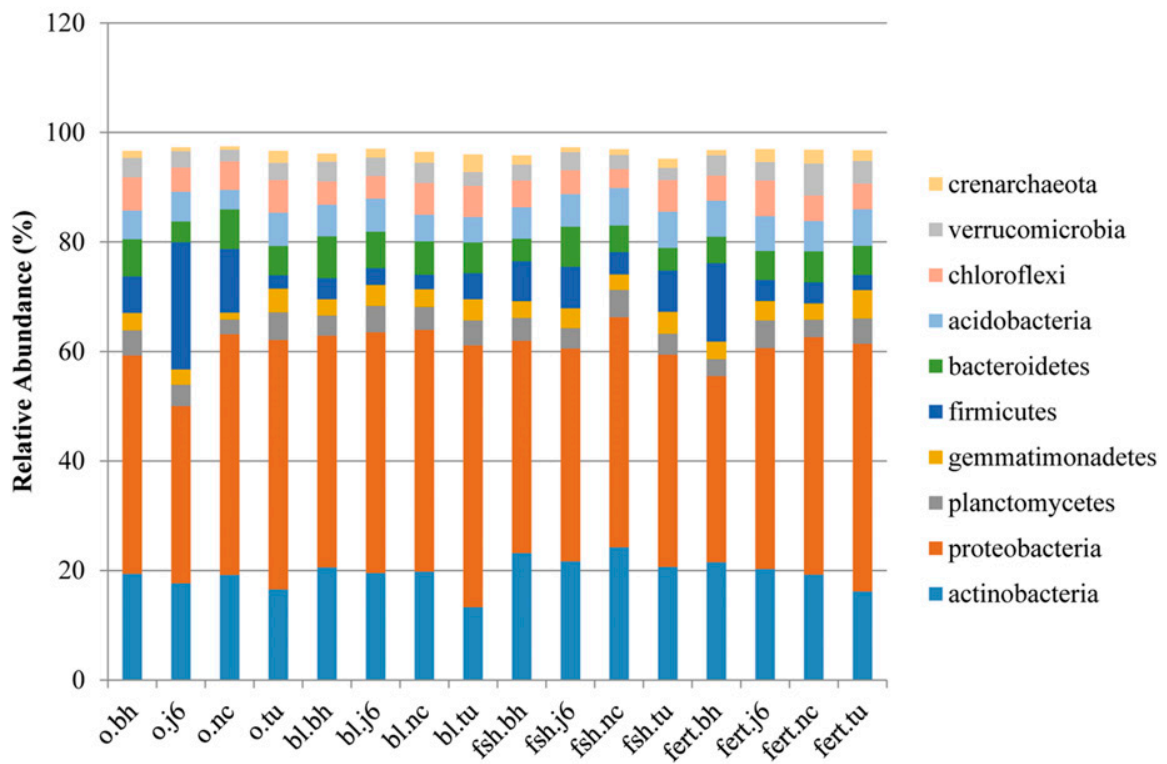

Fig. 1. Bacterial composition at the phylum level for each sample of sweetpotato rhizosphere. $0 \mathrm{bh}$ to $0 \mathrm{tu}=$ Control 'TU Purple', 'J6/66', 'NCC-58', 'Whatley'; bl = poultry litter; fsh = Magabloom (fish hydrolysate); fert $=$ NPK fertilizer all combined with the same four sweetpotato cultivars.

Table 5. Effect of fertilizer and organic amendments on bacterial relative abundance in sweetpotato rhizosphere at the genus and species taxonomic level.

\begin{tabular}{lllll}
\hline & Control & Poultry litter & NPK & Megabloom \\
\hline Genus & & & & \\
$\quad$ Flexibacter & $1.20 \mathrm{a}^{\mathrm{z}}$ & $0.90 \mathrm{ab}$ & $0.97 \mathrm{a}$ & $0.40 \mathrm{~b}$ \\
Mycobacterium & $1.33 \mathrm{~b}$ & $1.86 \mathrm{a}$ & $1.67 \mathrm{ab}$ & $1.91 \mathrm{a}$ \\
Nitrosococcus & $1.60 \mathrm{a}$ & $2.42 \mathrm{a}$ & $1.79 \mathrm{a}$ & $0.69 \mathrm{~b}$ \\
Nitrosomonadaceae & $1.70 \mathrm{ab}$ & $1.95 \mathrm{ab}$ & $2.38 \mathrm{a}$ & $1.04 \mathrm{~b}$ \\
Roseiflexus & $1.77 \mathrm{a}$ & $1.51 \mathrm{a}$ & $1.48 \mathrm{a}$ & $0.57 \mathrm{~b}$ \\
Rubrobacter & $1.85 \mathrm{~b}$ & $1.76 \mathrm{~b}$ & $2.29 \mathrm{ab}$ & $3.05 \mathrm{a}$ \\
Species & & & & \\
Novosphingobium & $0.72 \mathrm{a}$ & $0.91 \mathrm{a}$ & $0.80 \mathrm{a}$ & $0.36 \mathrm{~b}$ \\
Rhodospirillaceae & $0.52 \mathrm{~b}$ & $0.90 \mathrm{ab}$ & $0.85 \mathrm{a}$ & $0.97 \mathrm{a}$ \\
\hline
\end{tabular}

${ }^{\mathrm{z}}$ Means within rows accompanied by the same letter are not significantly different according to TukeyKramer's test at 0.05 level of probability.

Novosphingobium has the ability to degrade large aromatic rings, leading to a high diversity of environments in which they have been found, including oil-contaminated soil
(Kämpfer et al., 2011), surface water sediments (Balkwill et al., 1997; Liu et al., 2005; Sohn et al., 2004), and wastewater facilities (Fujii et al., 2003; Neef et al., 1999). Only 
recently, this group has been discovered in plant-associated habitats such as the internal stem of Gossypium hirsutum (Kämpfer et al., 2015), the rhizosphere of Arabidopsis thaliana (Gan et al., 2013), and surface of a crown gall tumor on grapevine (Lin et al., 2014). One suggestion for Novosphingobium association with plants in the rhizosphere is the presence of xenobiotic aromatic compounds. Root exudates contain various molecules that are structurally related to aromatic xenobiotics (Ledger et al., 2012) that can potentially serve to create an ecosystem favorable to those bacteria with the ability to catabolize such compounds.

Taxonomic response to varieties. Significant effects of cultivar were observed for Mycobacterium and Sinobacter. The population of Sinobacter increased in the rhizosphere of 'Whatley/Loretan' and Mycobacterium in the rhizosphere of 'TU Purple' compared with other cultivars (Table 6). 'Whatley/Loretan' significantly influenced the rhizosphere populations of Bradyrhizobium elkanii, Rhodospirillaceae sp., and Sinobacter sp. (Table 6) compared with 'TU Purple' and 'J6/66' but was not different from 'NCC-58'.

A significant interaction between the organic amendment and cultivar for Gemmatimonadaceae and Gemmatimonas (Table 7) and for Anaerolinaceae and Gemmatimonadaceae sp. (Table 8). Anaerolinaceae population increased significantly in the rhizosphere of 'J6/66' when NPK was applied compared with the control and the other amendments. Gemmatimonadaceae populations increased significantly when PL and NPK were applied compared with control. Gemmatimonadaceae significantly increased in the rhizosphere of 'Whatley/Loretan', when NPK was applied compared with control and the other organic amendments. Megabloom significantly decreased Gemmatimonadaceae population compared with control, NPK and PL in the rhizosphere of 'Whatley/Loretan', but increased significantly in the rhizosphere of 'NCC-58' when NPK and organic amendments were applied compared with the control (Table 8).

'TU Purple' and 'Whatley/Loretan' significantly affected the phylum Gemmatimonadetes at every taxonomical level, suggesting that these cultivars produce exudates that may attract certain bacterial groups. Bacteria belonging to this phylum are frequently detected in a variety of environments and are noted as one of the nine most common from the soil in 16S rRNA gene libraries. Janssen (2006) and Khodadad et al. (2011) also found that these bacteria are abundant in carbonrich soils, further suggesting that these bacteria may have influenced carbon content in the rhizosphere of these two cultivars. Gemmatimonadetes play a role in phosphorus cycling (Zhang et al., 2003), as they improve phosphorus removal in wastewater, and could play a similar role in the soil. The varying RA of Rhodospirillaceae sp. among the cultivars is worthy of note, as the capacity to fix molecular nitrogen is ubiquitous among members of Rhodospirillaceae, whereas the

Table 6. Effect of cultivars on bacterial relative abundance in sweetpotato rhizosphere at the genus and species taxonomic level.

\begin{tabular}{lcccc}
\hline & TU Purple & J6/66 & NCC-58 & Whatley/Loretan \\
\hline Genus & & & & \\
$\quad \begin{array}{l}\text { Mycobacterium } \\
\text { Sinobacter }\end{array}$ & $1.94 \mathrm{a}^{\mathrm{z}}$ & $1.60 \mathrm{ab}$ & $1.84 \mathrm{a}$ & $1.39 \mathrm{~b}$ \\
& $0.91 \mathrm{~b}$ & $1.03 \mathrm{~b}$ & $0.95 \mathrm{~b}$ & $1.72 \mathrm{a}$ \\
Species & & & & \\
$\quad$ Bradyrhizobium elkanii & $0.79 \mathrm{~b}$ & $0.94 \mathrm{~b}$ & $0.79 \mathrm{~b}$ & $1.38 \mathrm{a}$ \\
$\quad$ Rhodospirillaceae & $0.64 \mathrm{~b}$ & $0.71 \mathrm{~b}$ & $0.81 \mathrm{ab}$ & $1.09 \mathrm{a}$ \\
\hline
\end{tabular}

${ }^{\mathrm{z}}$ Means within columns within genus and species accompanied by the same letter are not significantly different according to Tukey-Kramer's test at 0.05 level of probability.

Table 7. Effect of fertilization and cultivar on bacterial composition in sweetpotato rhizosphere at the genus taxonomic level.

\begin{tabular}{llll}
\hline Genus & Treatment & Cultivar & Estimate \\
\hline Gemmatimonadaceae & Poultry litter & NCC-58 & $2.3646 \mathrm{a}$ \\
& Control & NCC-58 & $0.6962 \mathrm{~b}$ \\
& NPK & NCC-58 & $2.2638 \mathrm{ab}$ \\
& Megabloom & NCC-58 & $1.7106 \mathrm{ab}$ \\
& & & \\
Gemmatimonadaceae & Poultry litter & Whatley/Loretan & $2.7972 \mathrm{a}$ \\
& Control & Whatley/Loretan & $2.9307 \mathrm{a}$ \\
& NPK & Whatley/Loretan & $3.8371 \mathrm{a}$ \\
& Megabloom & Whatley/Loretan & $1.1969 \mathrm{~b}$ \\
Gemmatimonas & & & \\
& Poultry litter & Whatley/Loretan & $1.072 \mathrm{~b}$ \\
& Control & Whatley/Loretan & $1.3797 \mathrm{~b}$ \\
& NPK & Whatley/Loretan & $1.3473 \mathrm{~b}$ \\
& Megabloom & Whatley/Loretan & $2.8128 \mathrm{a}$ \\
\hline
\end{tabular}

${ }^{\mathrm{z}}$ Means within columns and within genus accompanied by the same letter are not significantly different according to Tukey-Kramer's test at 0.05 level of probability.

Table 8. Effect of fertilizer and organic amendments and cultivar on bacterial composition in sweetpotato rhizosphere at the species taxonomic level.

\begin{tabular}{lllc}
\hline Species & Treatment & \multicolumn{1}{c}{ Cultivar } & Estimate \\
\hline Anaerolinaceae & Poultry litter & \\
& Control & $\mathrm{J} 6 / 66$ & $1.47 \mathrm{~b}$ \\
& NPK & $\mathrm{J} 6 / 66$ & $0.84 \mathrm{~b}$ \\
& Megabloom & $\mathrm{J} 6 / 66$ & $2.21 \mathrm{a}$ \\
& & $\mathrm{J} 6 / 66$ & $1.37 \mathrm{~b}$ \\
Gemmatimonadaceae & & $\mathrm{J} 6 / 66$ & $2.61 \mathrm{a}$ \\
& Poultry litter & $\mathrm{J} 6 / 66$ & $1.76 \mathrm{~b}$ \\
& Control & $\mathrm{J} 6 / 66$ & $2.53 \mathrm{a}$ \\
& NPK & $\mathrm{J} 6 / 66$ & $2.44 \mathrm{ab}$ \\
Megabloom & & \\
& & NCC-58 & $2.36 \mathrm{a}$ \\
& Poultry litter & NCC-58 & $0.70 \mathrm{~b}$ \\
& Control & NCC-58 & $2.26 \mathrm{a}$ \\
& NPK & NCC-58 & $1.71 \mathrm{a}$ \\
Gemmatimonadaceae & Megabloom & Whatley/Loretan & $2.80 \mathrm{~b}$ \\
& & Whatley/Loretan & $2.93 \mathrm{~b}$ \\
& Poultry litter & Whatley/Loretan & $3.84 \mathrm{a}$ \\
& Control & Whatley/Loretan & $1.20 \mathrm{c}$ \\
\hline
\end{tabular}

${ }^{\mathrm{z}}$ Means within columns within species accompanied by the same letter are not significantly different according to Tukey-Kramer's test at 0.05 level of probability.

efficacy of the process varies among species (Madigan et al., 1984). This group, along with Bradyrhizobium elkanii (another known $\mathrm{N}$-fixer) was also highest in the 'Whatley/ Loretan' rhizosphere (also lowest in SOC and highest in $\beta$-NAG activity, although not significant. The abundant concentration of the closely related Azospirillium sp. (known AOB) is interesting, as this species is well known as associative nitrogen fixers, which can partly explain the ability of sweetpotato to grow in $\mathrm{N}$-deficient marginal soils (Mortley and Hill, 1990; Trotman et al., 1993).
The findings suggest that organic fertilizer and variety influenced selected microbial populations and enzymatic function within the soil rhizosphere of sweetpotato. The effects of organic amendments on bacterial composition varied as population differed significantly under the different organic amendments as bacteria involved in $\mathrm{C}$ and $\mathrm{N}$ cycling were dominant at every taxonomic level. Organic amendments had no significant impact on SOC but variety did, with soil from 'Whatley/Loretan' rhizosphere having lower SOC than other cultivars. Although variety did not affect enzyme activity, all amendments 
significantly increase ACP, ALKP, $\beta$-NAG, and $\beta$-Glu enzyme activity compared with the control, but there was no significant difference among treatment. The phyla Actinobacteria and Gemmatimonadetes were also found in the samples, which could explain the increased activity seen in $\beta$-GLU and $\beta$-glucosaminidase enzymes. Based on these findings, we gather that bacteria associated with $\mathrm{C}$ and $\mathrm{N}$ cycling under aerobic conditions can dominate in the rhizosphere of sweetpotato. Most importantly, these findings gave a better understanding of microbiome associated with sweetpotato that may not have been previously connected with this storage root crop. Not only were we able to elucidate the storage root microbiome of these particular cultivars, but also demonstrate differential responses of organic and inorganic fertilizers possibly allowing for more studies investigating alternative fertilization technology as well as nutrient uptake and the soil, plant, microbe interface.

\section{Literature Cited}

Ai, C., G. Liang, J. Sun, X. Wang, and W. Zhou. 2012. Response of ectracellular enzyme activities and microbial community in both the rhizosphere and bulk soil to long-term fertilization practices in a fluvo-aquic soil. Geoderma 173-174:330-333.

Baker, B. 2005. Brief History of Organic Farming and the National Organic Program. In: Organic Farming Compliance Handbook. Organic Materials Review Institute, Eugene, OR.

Balkwill, D.L., G.R. Drake, R.H. Reeves, J.K. Fredrickson, D.C. White, D.B. Ringelberg, D.P. Chandler, M.F. Romine, D.W. Kennedy, and C.M. Spadoni. 1997. Taxonomic study of aromatic degrading bacteria from deep-terrestrialsubsurface sediments and description of Sphingomonas aromaticivorans sp. nov., Sphingomonas subterranea sp. nov., and Sphingomonas stygia sp. nov. Intl. J. Syst. Bacteriol. 47:191-201.

Bowen, G.D. and A.D. Rovira. 1976. Microbial colonization of plant roots. Annu. Rev. Phytopathol. 114:121-144.

Boyhan, G., R.J. Hicks, R.L. Torrance, C.M. Riner, and C.R. Hill. 2010. Evaluation of poultry litter and organic fertilizer rate and source for production of organic short-day onions. HortTechnology 20:304-307.

Bruinsma, M., G.A. Kowalchuk, and J.A. Van Veen. 2003. Effects of genetically modified plants on microbial communities and processes in soil. Biol. Fertil. Soils 37:329-337.

Burns, R.G. 1983. Extracellular enzyme-substrate interactions in soil, p. 249. In: J.H. Slater, R. Whittenbury, and J.W.T. Wimpenny (eds.). Microbes in their natural environment. Cambridge University Press, Cambridge, UK.

CSPI. 1992. Sweetpotato nutrition. Washington D.C. USA. 24 Mar. 2018. <http://www.foodreference. $\mathrm{com} / \mathrm{html} /$ sweet-pot-nutrition.html $>$.

Chang, W.H., Y.F. Huang, T.S. Yeh, and J.F. Liu. 2010. Effect of purple sweetpotato leaves consumption on exercise-induced oxidative stress, and IL-6 and HSP72 levels. J. Appl. Physiol. 109:1710-1715.

Chaudhry, V., A. Rehman, A. Mishra, P.S. Chauhan, and C.S. Nautiyal. 2012. Changes in bacterial community structure of agricultural land due to long-term organic and chemical amendments. Microb. Ecol. 64:450-460.

Choi, J.H., C.Y. Choi, K.J. Lee, Y.P. Hwang, Y.C. Chung, and H.G. Jeong. 2009. Hepatoprotective effects of an anthocyanin fraction from purplefleshed sweet potato against acetaminopheninduced liver damage in mice. J. Med. Food $12: 320-326$.

Coleman, D.C., D.A. Crossley, and P.F. Hendrix. 2004. Fundamentals of soil ecology. 2nd ed. Elsevier Inc., Burlington, VT.

Collado, L.S., R.C. Mabesa, and H. Corke. 1999. Genetic variation in the physical properties of sweet potato starch. J. Agr. Food Chem. 47:4195-4201.

Crump, E.M., M.B. Perry, S. Gale, E. Crawford, and W.W. Kay. 2003. Lipopolysaccharide Oantigen antibody-based detection of the fish pathogen Flavobacterium psychrophilum. J. Mol. Microbiol. Biotechnol. 6:182-190.

Delate, K., M. Duffy, C. Chase, A. Holste, H. Friedrich, and N. Wantate. 2003. An economic comparison of organic and conventional grain crops in a long-term agroecological research (LTAR) site in Iowa. Amer. J. Altern. Agr. 18:59-69.

Edmeades, D.C. 2003. The long-term effects of manures and fertilisers on soil productivity and quality: A review. Nutr. Cycl. Agroecosyst. 66:165-180.

Eivazi, F. and M.A. Tabatabai. 1977. Phosphatases in soils. Soil Biol. Biochem. 9:167-172.

Ekenler, M. and M.A. Tabatabai. 2003. Tillage and residue management effects on betaglucosaminidase activity in soils. Soil Biol. Biochem. 35:871-874.

Failla, M.L., S.K. Thakkar, and J.Y. Kim. 2009. In vitro bioaccessibility of beta-carotene in orange fleshed sweet potato (Ipomoea batatas Lam.). J. Agr. Food Chem. 57:10922-10927.

FAO. 2005. FAOSTAT Database, Rome, Italy: Food and Agriculture Organization of the United States. 24 Mar. 2014. <http://apps. fao.org/default.jsp>

FAO. 2010. FaoStat: Agriculture Data. 24 Mar. 2014 $<$ http://faostat.fao.org/site/567/DesktopDefault.aspx?PageID=567\#ancor $>$.

Fujii, K., M. Satomi, N. Morita, T. Motomura, T. Tanaka, and S. Kikuchi. 2003. Novosphingobium tardaugens sp. nov., an oestradiol degrading bacterium isolated from activated sludge of a sewage treatment plant in Tokyo. Intl. J. Syst. Evol. Microbiol. 53:47-52.

Fulhage, C.D. and D.L. Pfost. 1994. Spreading poultry litter without lab analysis but with soil tests. Dept. of Agr., Univ. of Missouri Ext. WQ222.

Gan, H.M., A.O. Hudson, A.Y.A. Rahman, K.G. Chan, and M.A. Savka. 2013. Comparative genomic analysis of six bacteria belonging to the genus Novosphingobium: Insights into marine adaptation, cell-cell signaling and bioremediation. BMC Genomics 14:431.

Gaskell, M. and R. Smith. 2007. Nitrogen sources for organic vegetable crops. HortTechnology 17:431-441

Gianfreda, L. 2015. Enzymes of importance to rhizosphere processes. J. Soil Sci. Plant Nutr. 15:283-306.

Gutierrez-Miceli, F.A., J. Santiago-Borraz, J.A. Montes Molina, C.C. Nafate, M. Abud-Archila, M.A. Oliva Llaven, R. Rincon-Rosales, and L. Dendooven. 2007. Vermicompost as a soil supplement to improve growth, yield and fruit quality of tomato (Lycopersicum esculentum). Bioresour. Technol. 98:2781-2786.

Hawes, M.C., G. Curlango-Rivera, Z. Xiong, and J.O. Kessler. 2012. Roles of root border cells in plant defense and regulation of rhizosphere microbial populations by extracellular DNA 'trapping'. Plant Soil 355:1-16.

Herman, M.A.B., B.A. Nault, and C.D. Smart. 2008. Effects of plant growth promoting rhizo- bacteria on bell pepper production and green peach aphid infestation in New York. Crop Prot. 27:996-1002.

Horne, P.A. 2008. Integrated pest management for crops and pastures. CSIRO, Melbourne, Australia.

Janssen, P.H. 2006. Identifying the dominant soil bacterial taxa in libraries of $16 \mathrm{~S}$ rRNA and 16S rRNA genes. Appl. Environ. Microbiol. 72:1719-1728.

Jett, L.W. and W.A. Mulkey. 1996. Nitrogen fertilizer effects on growth and yield of sweetpotato. HortScience 31:759-765.

Kämpfer, P., C.C. Young, H.J. Busse, S.Y. Lin, P.D. Rekha, A.B. Arun, W.M. Chen, F.T. Shen, and Y.H. Wu. 2011. Novosphingobium soli $\mathrm{sp}$ nov., isolated from soil. Intl. J. Syst. Evol. Microbiol. 61:259-263.

Kämpfer, P., K. Martin, J.A. McInroy, and S.P. Glaeser. 2015. Novosphingobium gossypii sp. nov., isolated from Gossypium hirsutum. Intl. J. Syst. Evol. Microbiol. 65:2831-2837.

Kennedy, A.C. 1995. Soil microbial diversity in agricultural systems, p. 249. In: R. Olson, F. Francis, and S. Kaffka (eds.). Exploring the role of diversity in sustainable agriculture. Amer. Soc. of Agr., Madison, WI.

Khodadad, C.L., A.R. Zimmerman, S.J. Green, S. Uthandi, and J.S. Foster. 2011. Taxa-specific changes in soil microbial community composition induced by pyrogenic carbon amendments. Soil Biol. Biochem. 43:385-392.

Klonsky, K. 2000. Forces impacting the production of organic foods. Agr. Human Values 17:233243.

Lauber, C.L., M. Hamady, R. Knight, and N. Fierer. 2009. Pyrosequencing-based assessment of soil $\mathrm{pH}$ as a predictor of soil bacterial community composition at the continental scale. Appl. Environ. Microbiol. 75:51115120.

Ledger, T., A. Zúñiga, T. Kraiser, P. Dasencich, R. Donoso, D. Pérez-Pantoja, and B. González. 2012. Aromatic compounds degradation plays a role in colonization of Arabidopsis thaliana and acacia cavern by Cupriavidus pinatubonensis JMP134. Antonie van Leeuwenhoek 101:713-723.

Leff, J.W. and N. Fierer. 2013. Bacterial communities associated with the surfaces of fresh fruits and vegetables. PLoS One 8:e59310.

Lin, S.Y., A. Hameed, Y.C. Liu, Y.H. Hsu, W.A. Lai, H.I. Huang, and C.C. Young. 2014. Novosphingobium arabidopsis sp. nov., a DDT-resistant bacterium isolated from the rhizosphere of Arabidopsis thaliana. Intl. J. Syst. Evol. Microbiol. 64:594-598.

Li, R., E. Khafipour, D.O. Krause, M.H. Entz, and T.R. de Kievit. 2012. Pyrosequencing reveals the influence of organic and conventional farming systems on bacterial communities. PLoS One 7:e51897, doi: 10.1371/journal. pone.0051897.

Liu, Z.P., B.J. Wang, Y.H. Liu, and S.J. Liu. 2005. Novosphingobium taihuense sp. nov., a novel aromatic-compound-degrading bacterium isolated from Taihu Lake, China. Intl. J. Syst. Evol. Microbiol. 55:1229-1232.

Lynch, J.M. and J.M. Whipps. 1990. Substrate flow in the rhizosphere. Plant Soil 129:1-10.

Madigan, M.I., S.S. Cox, and R.A. Stegeman. 1984. Nitrogen fixation and nitrogenase activities in members of the family Rhodospirillaceae. J. Bacteriol. 157:73-78.

Mikkelsen, R. and T.K. Hartz. 2008. Nitrogen sources for organic crop production. Better Crops Plant Food 92:16-19. 
Moore-Kucera, J. and R.P. Dick. 2008. PLFA profiling of microbial community structure and seasonal shifts in soils of a Douglas-fir chronosequence. Microb. Ecol. 55:500-511.

Mortley, D., C. Bonsi, and F.K. Amagloh. 2017. The influence of days after planting on root yield and quality of orange- and purple-fleshed sweetpotato (Ipomoea batatas (L.) Lam) cultivars assessed in the Northern Region, Ghana. J. Ghana Sci. Assoc. 17:9-15.

Mortley, D.G. and W.A. Hill. 1990. Sweetpotato growth and nitrogen content following nitrogen application and inoculation with Azospirillum. HortScience 25:758-759.

Ndiaye, E.L., J.M. Sandeno, D. McGrath, and R.P. Dick. 2000. Integrative biological indicators for detecting change in soil quality. Amer. J. Altern. Agr. 15:26-36.

Neef, A., R. Witzenberger, and P. Kampfer. 1999. Detection of sphingomonads and in situ identification in activated sludge using 16S rRNA-targeted oligonucleotide probes. J. Ind. Microbiol. Biotechnol. 23:261-267.

Parham, J.A. and S.P. Deng. 2000. Detection, quantification and characterization of betaglucosaminidase activity in soil. Soil Biol. Biochem. 32:1183-1190.

SAS Institute Inc. 2009. The SAS system for windows, Version 9.2. SAS Institute Inc. Cary, NC.

Shange, R.S., R.O. Ankumah, A.M. Ibekwe, R. Zabawa, and S.E. Dowd. 2012. Distinct soil bacterial communities revealed under a diversely managed agroecosystem. PLoS One 7:e40338.

Sohn, J.H., K.K. Kwon, J.H. Kang, H.B. Jung, and S.J. Kim. 2004. Novosphingobium pentaromativorans sp. nov., a high-molecular-mass polycyclic aromatic hydrocarbon-degrading bacterium isolated from estuarine sediment. Intl. J. Syst. Evol. Microbiol. 54:1483-1487.

Sugiyama, A., J.M. Vivanco, S.S. Jayanty, and D.K. Manter. 2010. Pyrosequencing assessment of soil microbial communities in organic and conventional potato farms. Plant Dis. 94:1329-1335.

Sun, H.Y., S.P. Deng, and W.R. Raun. 2004. Bacterial community structure and diversity in a century-old manure-treated agroecosystem. Appl. Environ. Ecol. 70:5868-5874.

Tabatabai, M.A. and W.A. Dick. 2002. Enzymes in soil: Research and developments in measuring activities, p. 539-565. In: R.G. Burns and R.P. Dick (eds.). Enzymes in the environment. Marcel Dekker, New York, NY.

Treadwell, D.D., N.G. Creamer, G.D. Hoyt, and J.R. Schultheis. 2008. Nutrient management with cover crops and compost affects development and yield in organically managed sweetpotato systems. HortScience 43:1423-1433.

Trotman, A.A., W.A. Hill, D.G. Mortley, P.P David, and P.A. Loretan. 1993. Response of hydroponically grown sweetpotato to inoculation with Azospirillum. HortScience 28:266.

Vessey, J.K. 2003. Plant growth promoting rhizobacteria as biofertilizers. Plant Soil 255:571586.

Villordan, A., D. LaBonte, N. Firon, and E. Carey. 2013. Variation in nitrogen rate and local availability alter root architecture attributes at the onset of storage root initiation in 'Beauregard' sweetpotato. HortScience 48:808-815.

Walkley, A. and I.A. Black. 1934. An examination of the Degtjareff method for determining or- ganic carbon in soils: Effect of variations in digestion conditions and of inorganic soil constituents. Soil Sci. 63:251-263.

Wang, Z., H. Zong, H. Zheng, G. Liu, L. Chen, and B. Xing. 2015. Reduced nitrification and abundance of ammonia-oxidizing bacteria in acidic soil amended with biochar. Chemosphere 138:576-583.

Wen-yuan, H. 2007. Tight supply and strong demand may raise U.S. nitrogen fertilizer prices. Amber Waves 5:7.

Whitmore, A.P. 2007. Determination of the mineralization of nitrogen from composted chicken manure as affected by temperature. Nutr. Cycl. Agroecosyst. 77:225-232.

Widmer, F., F. Rasche, M. Hartmann, and A. Fliessbach. 2006. Community structures and substrate utilization of bacteria in soils from organic and conventional farming systems of the DOK long-term field experiment. Appl. Soil Ecol. 33:294-307.

Worthington, V. 2001. Nutritional quality of organic versus conventional fruits, vegetables, and grains. J. Altern. Complement. Med. 7: 161-173.

Wu, Q., R. Knowles, and D.F. Niven. 1994. O 2 regulation of denitrification in Flexibacter canadensis. Can. J. Microbiol. 40:916-921.

Zhang, H., Y. Sekiguchi, S. Hanada, P. Hugenholtz, H. Kim, Y. Kamagata, and K. Nakamura. 2003. Gemmatimonas aurantiaca gen. nov., sp. nov., a Gram-negative, aerobic, polyphosphateaccumulating microorganism, the first cultured representative of the new bacterial phylum Gemmatimonadetes phyl. nov. Intl. J. Syst. Evol. Microbiol. 53:1155-1163. 